\title{
Challenges of Green Management in Iran
}

\author{
M. Abbaspour ${ }^{1} \&$ S. Khadivi ${ }^{2}$ \\ ${ }^{1}$ Department of Mechanical Engineering, \\ Sharif University of Technology, Iran \\ ${ }^{2}$ College of Environment and Energy, Islamic Azad University, Iran
}

\begin{abstract}
From the sustainable development perspective, there is no contradiction between economic growth and environmental enhancement. The realization of the goals foreseen by the sustainable development provides a logical and sustainable vision to the economic, social, cultural and political activities. It improves sustainable planning in the environmental sector through optimal use of resources and protection of the environment.

One of the main instruments in this regard in Iran is the implementation of a proper Consumption Model. The fourth five year National Development Plan of Iran (2005-2010) emphasizes the implementation of the Consumption Model in its $66^{\text {th }}$ article and highly recommends the establishment of the Green Government as a conservation modality in public institutions.

In light of the conducted research in establishment of the Green Government and its related agencies, the present challenges in terms of managerial, technical and cultural obstacles could be further studied at the national level. From the technical perspective, lack of adequate scientific knowledge for the optimization of materials and energy consumption and lack of knowledge and training, as well as undefined responsibilities at the managerial level for the establishment of the Green Management system and protection of national resources, directly contribute to this predicament. Other factors, such as an inequitable subsidized system, the widespread bureaucratic network and the need for privatization of various sectors, are indirectly responsible as well. The present article studies the above-mentioned challenges and provides recommendations to facilitate the establishment of Green Management.
\end{abstract}

Keywords: Green Management, sustainable development, economic growth, Green Government. 


\section{Introduction}

In today's world, management is considered as a science that requires new technologies suitable for the scientific advancements of the $21^{\text {st }}$ century. This is the century during which mankind is trying relentlessly to conquer the unknown aspects of the earth and the cosmos [1]. This endeavor is toward the development and the proper use of natural resources. Obviously, the inappropriate and unwise use of natural resources without the concepts of sustainable development would only lead to the destruction of these limited resources. Sustainable development encompasses all the issues including economic, political, social and environmental. Thus, the environmental concerns in conjunction with other issues are involved in the concept of sustainable development. Nonetheless, one of the outcomes of sustainable development is environmental protection. Due to the widespread use of environmental management in human activities, the new terminologies, such as Green Management, Green Productivity, Green Government, etc., are being used in the management system [2]. Since environment and development are interrelated, it is essential to use managerial instruments to minimize the adverse effects of the development on the environment [1].

In other words, Green Management is the environmental performance of organizations, agencies and companies for reduction in water and energy consumption as well as curbing unnecessary consumption based on the consumption model and optimal use of resources [3].

In Iran, article 50 of constitution law pays special attention to the well being of the environment. Since 1948 to the present, the Iranian governmental has had nine five year development plans. It was not until 1994 when some serious attention was paid towards the sustainable means of the development plan. In spite of all the remarks, many steps should be taken in order to convenience all authorities to pay enough attention to this important issue.

Iran, with a population of 67 million and an average annual energy demand increase of $10 \%$, is a fast growing developing country. The inefficient use of natural resources can cause considerable negative environmental impacts.

As a result, in Iran, the Green Management Act for the governmental sector was approved by the Council of Ministers in Line P, Note 20 of budget Law in 2003 fiscal year [5].

\section{Performed activities on Green Management in Iran}

The Department of the Environment has identified the following activities as its primary tasks for the establishment and promotion of Green Management in the country:

1- Design and publication of 12 volumes of Green Government documents including guidelines, work plans and check lists of activities on reduction of consumption in the ministries and governmental organizations, production and industrial units, 
commercial centers, tourism and sports complexes, cultural and educational centers, health centers and military installations.

2- Preparation of checklists for consumption reduction based on the guidelines of the Green Management system.

3- Design of Green Management standards similar to ISO 14000 for public organizations and centers, and development of a special certificate for establishment of a Green Management standard.

4- Development of various guidelines and work plans for promotion of environmental culture and public awareness, including guidelines for conservation of resources and protection of the environment as a component of the Green Government.

5- Preparation of a newsletter for the Green Management System (10 publications).

6- Design and establishment of a Green Government site for dissemination of information and sharing of past experiences on the Green Management system.

7- Design of educational posters for the Green Management system.

8- Educational training for the Green Management system including:

- conducting 51 sensitizing meetings in ministries and other national organizations;

- conducting 35 explanatory meetings for the members of the ministries and the executive organizations of the country;

- consultation for 28 organizations towards the establishment of the green groups;

- establishment of the Green Government booth and holding educational workshops in the $5^{\text {th }}$ International Environmental Fair in July 2004.

9- Educational activities and holding seminars on the Green Management system at national and provincial levels.

The establishment of the Green Management system in 20 governmental organizations (as pilot sites) has resulted in an annual conservation of electricity of about 3,436 thousand Megawatt-Hour (128 million Euros) used for lighting purposes, an annual conservation of paper in the amount of 6.7 thousand tons ( 6 million Euros), an annual conservation of water totaling 10,448 thousand cubic meters and a $30 \%$ reduction in the consumption of gasoline $[5,6]$.

The Green Management system with the objective of water, electricity, gas, paper and gasoline conservation is being approved, designed and implemented in governmental institutions and undoubtedly the diligent execution of the proposed guidelines and standards with the cooperation of the green groups would attain the envisioned goals [7].

\section{Specifications of Green Management in Iran}

There is public misunderstanding in the differences in the execution of different managerial systems, such as ISO14000, HSE, IMS and GM. 
Table 1: $\quad$ Comparison of Green Management with ISO 14000 and HSE.

\begin{tabular}{|c|c|c|}
\hline ISO 14000 & Green Management & HSE \\
\hline $\begin{array}{l}\text { 1- At international } \\
\text { level } \\
\text { 2- Based on } \\
\text { responsibility, } \\
\text { planning, execution, } \\
\text { measurement, feedback } \\
\text { and continual } \\
\text { improvement } \\
\text { 3- Systematic and } \\
\text { qualitative } \\
\text { 4- Requires third party } \\
\text { auditing and } \\
\text { certification } \\
\text { 5- Emphasis on } \\
\text { stakeholders } \\
\text { 6- Emphasis on rules } \\
\text { and regulations } \\
\text { 7- Voluntary } \\
\text { participation }\end{array}$ & $\begin{array}{l}\text { 1- At National Level } \\
\text { 2- Based on organization's } \\
\text { performance } \\
\text { 3- No need for third party } \\
\text { auditing (based on self- } \\
\text { assessment) } \\
\text { 4- Emphasis on the internal } \\
\text { structure of the organization } \\
\text { 5-Optomization of } \\
\text { consumption and } \\
\text { conservation } \\
6 \text { - Comparing various } \\
\text { organizations with each } \\
\text { other } \\
7 \text { - Improvement of } \\
\text { productivity through } \\
\text { reduction of data }\end{array}$ & $\begin{array}{l}\text { 1- At international } \\
\text { level } \\
\text { 2- Based on health, } \\
\text { safety and } \\
\text { environment } \\
\text { 3- Systematic and } \\
\text { qualitative } \\
\text { 4- Obligations } \\
\text { within the } \\
\text { organizational } \\
\text { structure } \\
\text { 5- Emphasis on } \\
\text { environment, health } \\
\text { and personal } \\
\text { hygiene } \\
6 \text { - Emphasis on } \\
\text { rules and regulations } \\
7-\text { Voluntary } \\
\text { participation }\end{array}$ \\
\hline
\end{tabular}

One of the outcomes of management systems like ISO 14000, HSE, IMS and others is the enforcement of Green Management, although it is possible to directly implement Green Management in governmental institutions. Table 1 provides a comparison of the Green Management system with ISO 14000 and HSE specifications.

It is important to point out that the first step in the establishment of a Green Management system in various sectors of the country is the government's accountability and responsibility to make Green Management a mandatory concept in its structure.

According to the principles announced by the Green Government secretariat office, they are taking steps in training, preparation of checklists and actual reduction of consumptions.

Table 2 indicates the challenges, opportunities, weaknesses and strengths for the establishment of the Green Government in the major sectors of the country. Therefore the following managerial and technical requirements should be considered.

\section{Requirements of Green Management execution in Iran}

The present study indicates that the annual consumption of water in different sectors in Iran is about 94 billion cubic meters, the consumption of paper per capita is $3.5 \mathrm{~kg}$, and the energy consumption is about 932 million barrels of oil 
Table 2: $\quad$ SWOT for establishment of Green Management in various sectors.

\begin{tabular}{|c|c|c|c|c|c|}
\hline No. & Sector & Threats & Opportunities & Weaknesses & Strengths \\
\hline 1 & $\begin{array}{l}\text { Buildings: } \\
\text { Business } \\
\text { Public } \\
\text { Private } \\
\text { Commercial }\end{array}$ & $\begin{array}{l}\text { - Lack of proper } \\
\text { regulations for } \\
\text { design and } \\
\text { construction of } \\
\text { buildings } \\
\text { - Lack of access } \\
\text { to new } \\
\text { technologies for } \\
\text { optimization of } \\
\text { water and } \\
\text { energy } \\
\text { consumption } \\
\text { - Lack of public } \\
\text { awareness in } \\
\text { regard to Green } \\
\text { Management } \\
\text { - Lack of a } \\
\text { comprehensive } \\
\text { and strategic } \\
\text { plan for } \\
\text { development of } \\
\text { the construction } \\
\text { sector in the } \\
\text { country } \\
\text { - Energy } \\
\text { subsidies in the } \\
\text { sector } \\
\text { - Lack of } \\
\text { control and } \\
\text { adequate } \\
\text { regulations for } \\
\text { manufacturing } \\
\text { of energy } \\
\text { consuming } \\
\text { equipment in the } \\
\text { buildings } \\
\text { - Lack of a } \\
\text { single focal } \\
\text { coint for } \\
\text { construction } \\
\text { contry }\end{array}$ & $\begin{array}{l}\text { - Use of public } \\
\text { organizations' } \\
\text { facilities like } \\
\text { IFCO, SABA } \\
\text { for } \\
\text { optimization of } \\
\text { energy } \\
\text { consumption } \\
\text { - Use of mass } \\
\text { media like TV } \\
\text { stations to } \\
\text { disseminate } \\
\text { information to } \\
\text { the public on } \\
\text { the proper } \\
\text { usage of } \\
\text { resources in the } \\
\text { households } \\
\text { - The potential } \\
\text { of establishing } \\
\text { Green } \\
\text { Management } \\
\text { system in } \\
\text { administrative } \\
\text { and public } \\
\text { buildings } \\
\text { - The potential } \\
\text { of utilizing new } \\
\text { equipment like } \\
\text { solar water } \\
\text { heaters in one } \\
\text { and two story } \\
\text { buildings } \\
\text { - The potential } \\
\text { of eliminating } \\
\text { the energy } \\
\text { subsidies in the } \\
\text { construction } \\
\text { sector }\end{array}$ & $\begin{array}{l}\text { - High } \\
\text { consumption of } \\
\text { energy by the } \\
\text { construction } \\
\text { equipment and } \\
\text { materials } \\
\text { - High energy } \\
\text { consumption of } \\
\text { new equipment in } \\
\text { the buildings } \\
\text { - Utilization of } \\
\text { inappropriate } \\
\text { materials in the } \\
\text { buildings } \\
\text { - Unsuitable } \\
\text { design and lack } \\
\text { attention to } \\
\text { climate conditions } \\
\text { optimization of } \\
\text { energy use } \\
\text { - Outdated and old } \\
\text { buildings } \\
\text { - Lack of public } \\
\text { - Lack of thermal, } \\
\text { water and acoustic } \\
\text { insulations in most } \\
\text { of the buildings } \\
\text { - Hith high } \\
\text { required for repair } \\
\text { of buildings } \\
\text { - The outdated and } \\
\text { old equipment } \\
\text { - } \\
\text { - }\end{array}$ & $\begin{array}{l}\text { - Regulations } \\
\text { supporting } \\
\text { energy } \\
\text { conservation } \\
\text { in buildings } \\
\text { - Labeling of } \\
\text { household } \\
\text { appliances } \\
\text { with energy } \\
\text { consumption } \\
\text { stickers } \\
\text { - Offering } \\
\text { energy } \\
\text { management } \\
\text { courses in } \\
\text { universities } \\
\text { - Providing } \\
\text { fuel } \\
\text { conservation } \\
\text { credits by } \\
\text { IFCO } \\
\text { - More } \\
\text { frequent } \\
\text { usage of solar } \\
\text { water heaters } \\
\text { - The } \\
\text { possibility of } \\
\text { high energy } \\
\text { conservation } \\
\text { in the } \\
\text { building with } \\
\text { little cost }\end{array}$ \\
\hline
\end{tabular}


Table 2: $\quad$ Continued.

\begin{tabular}{|c|c|c|c|c|c|}
\hline No. & Sector & Threats & Opportunities & Weaknesses & Strengths \\
\hline 2 & $\begin{array}{l}\text { Transportation: } \\
\text { Urban } \\
\text { Roads } \\
\text { Railroads } \\
\text { Naval } \\
\text { Aviation }\end{array}$ & 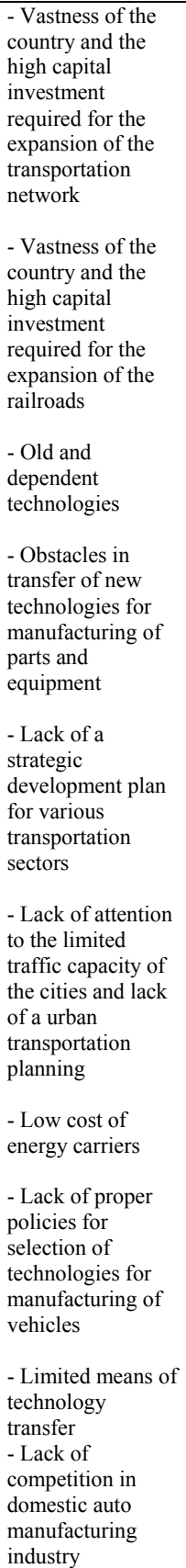 & $\begin{array}{l}\text { - Factories and } \\
\text { high capital } \\
\text { investments in } \\
\text { the recent years } \\
\text { - Expanding } \\
\text { market for quality } \\
\text { vehicles } \\
\text { - International } \\
\text { transit routes } \\
\text { across the } \\
\text { country } \\
\text { - Aviation transit } \\
\text { routes for } \\
\text { international } \\
\text { flights } \\
\text { - Numerous } \\
\text { airports in the } \\
\text { country } \\
\text { - The linkage of } \\
\text { the national } \\
\text { railroad network } \\
\text { to Turkey, } \\
\text { Azerbaijan and } \\
\text { Turkmenistan } \\
\text { - The potential to } \\
\text { eliminate or } \\
\text { reduce the energy } \\
\text { subsidies in this } \\
\text { sector } \\
\text { - Large natural } \\
\text { gas resources and } \\
\text { the potential to } \\
\text { use it in vehicles } \\
\text { - Potential to } \\
\text { eliminate or } \\
\text { reduce the } \\
\text { customs on } \\
\text { imported parts } \\
\text { and high quality } \\
\text { equipment }\end{array}$ & $\begin{array}{l}\text { - Old private } \\
\text { vehicles } \\
\text { - Outdated public } \\
\text { transportation system } \\
\text { - Old railroad } \\
\text { network } \\
\text { - Inadequate safety } \\
\text { of the roads } \\
\text { - High energy } \\
\text { intensity in road } \\
\text { transportation } \\
\text { - Old technology in } \\
\text { production of } \\
\text { vehicles } \\
\text { - High cost of quality } \\
\text { vehicles } \\
\text { - Improper use of } \\
\text { private vehicles } \\
\text { - Neglecting the } \\
\text { environmental } \\
\text { standards in } \\
\text { manufacturing and } \\
\text { usage of vehicles } \\
\text { - Lack of private } \\
\text { sector's involvement } \\
\text { in transport of } \\
\text { passengers and } \\
\text { goods }\end{array}$ & 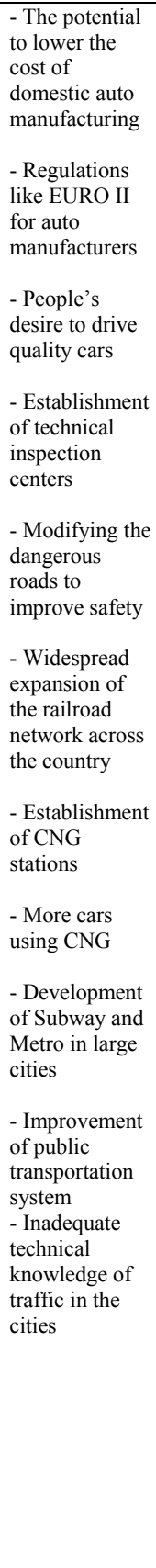 \\
\hline
\end{tabular}


Table 2: $\quad$ Continued.

\begin{tabular}{|c|c|c|c|c|c|}
\hline No. & Sector & Threats & Opportunities & Weaknesses & Strengths \\
\hline 3 & $\begin{array}{l}\text { Industry: } \\
\text { Various } \\
\text { Industrial } \\
\text { Sectors }\end{array}$ & $\begin{array}{l}\text { - Blocking the } \\
\text { transfer of } \\
\text { advanced } \\
\text { technologies into } \\
\text { the country } \\
\text { - Inadequate } \\
\text { number of experts } \\
\text { - High cost of } \\
\text { modification and } \\
\text { improvement of } \\
\text { industrial structure } \\
\text { - Lack of } \\
\text { knowledge about } \\
\text { pollution control } \\
\text { equipment } \\
\text { - Lack of } \\
\text { comprehensive } \\
\text { plans for } \\
\text { sustainable } \\
\text { development of the } \\
\text { industries } \\
\text { - Low cost of } \\
\text { energy in the } \\
\text { country }\end{array}$ & $\begin{array}{l}\text { - Cheap technical } \\
\text { work force } \\
\text { - Potential to } \\
\text { establish energy } \\
\text { management } \\
\text { system in most of } \\
\text { industries } \\
\text { - Potential to use } \\
\text { clean fuels in } \\
\text { industries } \\
\text { - Potential to } \\
\text { establish clean } \\
\text { industries in the } \\
\text { country }\end{array}$ & $\begin{array}{l}\text { - Outdated industries } \\
\text { - Lack of } \\
\text { responsibility of the } \\
\text { industrial } \\
\text { managements to } \\
\text { protect the } \\
\text { environment } \\
\text { - Lack of adequate } \\
\text { expertise } \\
\text { - High energy } \\
\text { intensity in the } \\
\text { industries } \\
\text { - Dispersion of } \\
\text { industries across the } \\
\text { country } \\
\text { - High cost of } \\
\text { production } \\
\text { - Inappropriate site } \\
\text { selection for the } \\
\text { industries }\end{array}$ & $\begin{array}{l}\text { - Abundance of } \\
\text { raw materials } \\
\text { - Low cost of } \\
\text { emission control } \\
\text { in domestic } \\
\text { industries in } \\
\text { comparison to } \\
\text { the developed } \\
\text { countries } \\
\text { - Establishment } \\
\text { of energy } \\
\text { management } \\
\text { system in some } \\
\text { industries } \\
\text { - Establishment } \\
\text { of IMS, HSE, } \\
\text { ISO } 14001 \text { in } \\
\text { most industries } \\
\text { - Establishment } \\
\text { of Research and } \\
\text { Development } \\
\text { Unit in } \\
\text { industries }\end{array}$ \\
\hline 4 & $\begin{array}{l}\text { Production } \\
\text { \& Transfer } \\
\text { of power : } \\
\text { Hydro- } \\
\text { electrical } \\
\text { Power } \\
\text { Plants } \\
\text { Thermal } \\
\text { Power } \\
\text { Plants } \\
\text { Power } \\
\text { Transfer } \\
\text { Lines }\end{array}$ & $\begin{array}{l}\text { - Inadequate } \\
\text { investment for } \\
\text { establishment of } \\
\text { power plants and } \\
\text { expansion of the } \\
\text { power grid } \\
\text { - High annual } \\
\text { power demand by } \\
\text { various sectors in } \\
\text { the country } \\
\text { - Inappropriate } \\
\text { transfer of } \\
\text { technology, mostly } \\
\text { Chinese and } \\
\text { Russian } \\
\text { technologies }\end{array}$ & $\begin{array}{l}\text { - Potential to use } \\
\text { solar energy for } \\
\text { production of } \\
\text { electricity } \\
\text { connected to the } \\
\text { national network } \\
\text { - Potential to use } \\
\text { solar water heaters } \\
\text { in warm climates } \\
\text { - Potential to use } \\
\text { independent } \\
\text { systems in remote } \\
\text { and rural areas in } \\
\text { order to prevent } \\
\text { energy losses } \\
\text { - Potential to } \\
\text { generate } \\
\text { electricity by } \\
\text { hydro-electrical } \\
\text { power plants } \\
\text { - Possibility of } \\
\text { constructing } \\
\text { thermal power } \\
\text { plants at the } \\
\text { coastal areas and } \\
\text { on the banks of } \\
\text { rivers }\end{array}$ & $\begin{array}{l}\text { - High energy } \\
\text { intensity in thermal } \\
\text { power plants } \\
\text { - High emission of } \\
\text { pollutants from } \\
\text { thermal power plants } \\
\text { - High loses of energy } \\
\text { in the power grids } \\
\text { - Unscientific } \\
\text { expansion of power } \\
\text { grids } \\
\text { - Highly varying } \\
\text { electricity } \\
\text { consumption peaks } \\
\text { throughout the } \\
\text { network }\end{array}$ & $\begin{array}{l}\text { - Low } \\
\text { investment for } \\
\text { establishment of } \\
\text { energy } \\
\text { management in } \\
\text { the power plants } \\
\text { - Appropriate } \\
\text { development } \\
\text { plans for the } \\
\text { power plants in } \\
\text { the country } \\
\text { - Establishment } \\
\text { of IMS, HSE, } \\
\text { ISO 14001, ISO } \\
9000 \text { in the } \\
\text { power sector } \\
\text { - Utilization of } \\
\text { control systems } \\
\text { in some of the } \\
\text { power plants }\end{array}$ \\
\hline
\end{tabular}


equivalent, with an annual increase of about 10\%. Applying Green Management can reduce this consumption respectively by $10 \%, 10 \%$ and $25-30 \%$.

For the proper implementation of the Green Management system, the following managerial and technical requirements are to be emphasized.

\subsection{Managerial requirements}

In order to establish the Green Management system and the attainment of its macro and micro objectives, the senior management of the organization should accept the following responsibilities:

- reduction in consumption of energy carriers;

- $\quad$ reduction in water consumption;

- reduction in consumption of raw materials (paper and etc...).

One of the pillars of any given management system is the enhancement of public awareness in its various sectors. The training of personnel is one of the essentials for the establishment of the Green Management system in different levels of public organizations.

\subsection{Technical requirements}

Another pillar of the Green Management system is the establishment of a control and monitoring system as a necessary instrument for the continual improvement of the environment and the protection of resources. Such a control and monitoring system requires the following components:

a. Monitoring of the optimization measures for paper, water, energy and etc... consumption.

b. Monitoring and control of the educational activities on protection of the environment and conservation of resources.

c. Monitoring and control of environmental quality through:

- regular sampling and measurement of noise pollution during various time periods (parameters such as Lmin, Lmax, Leq, SPL);

- regular sampling and measurement of air quality parameters during various seasons (parameters such as PM10, NO2, SO2, CO);

- qualitative and quantitative sampling and analysis of solid waste components;

- $\quad$ sampling and analysis of physical, chemical and biological parameters of sewage and waste waters.

The accountability and responsibility of the senior management of the organization is a must in proper implementation of these activities. Figure 1 provides the suitable flow of activities and the proper establishment of the Green Management system in such organizations.

\section{Conclusion}

Based on the assessment of the limited establishment of the Green Management system in the country, there is considerable potential for conservation in various sectors. The promotion of green culture, creation of green expert groups and observance of Green Government standards are essential in attaining the envisioned objectives. As a result, the following managerial measurements are recommended: 


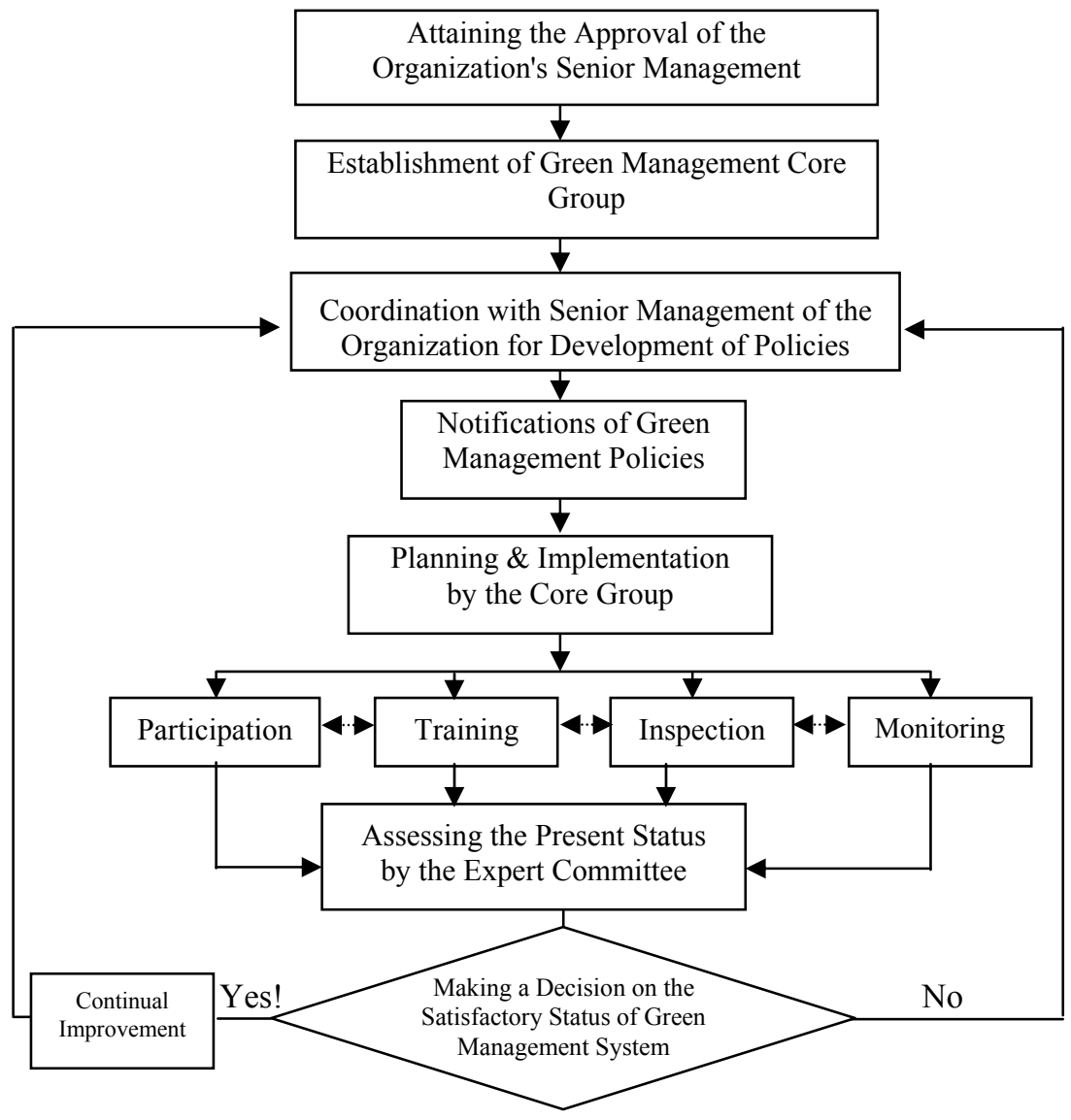

Figure 1: Establishment chart of Green Management system in national organizations and institution.

- The quality and conservation of resources based on the articles of the $4^{\text {th }}$ National Development Plan are necessary in preparation of the sectoral documentations, execution of provincial activities and clarification of development plans for the comprehensive establishment of and enhancement of quality management.

- In order to create the required background, improvement of productivity, quality, competitiveness, creativity and innovation in consumption optimization is needed.

- The sensitization of the executive institutions, organizations and private companies could be attained by the following steps:

- increasing the awareness of the managers and promotion of the Green Management system;

- creation of the green groups in the form of environmental offices situated in the organizations and institutions; 
- $\quad$ training of the Green Management system at the national level;

- general and specialized trainings for the members of the green groups;

- $\quad$ creation of a suitable environment for cooperation of green groups and participation of the employees;

- Creation of physical and spiritual incentives for conservation of resources and optimized consumption.

- Development of short term and long term goals for Green Management.

- Preparation of a study plan and the executive measures of Green Management.

- Utilization of documents and guidelines for Green Government in the organizations.

- Assessing the implementation potential of the plans by the green group.

- Operational measures for mitigation of environmental pollution and conservation of resources.

- Preparation of the progress report of the organizations.

- Annual environmental auditing in terms of Green Management operations and their review.

- Submitting progress report of the organizations to the Green Government Secretariat.

- Implementation of the National Green Management System Act.

- Preparation of promotional policies and plans for expansion of Green Management in the country.

- Utilization of NGOs' cooperation in expansion of Green Management in the country.

- Altering the energy subsidies from direct payments of fuel subsidies to the implementing agencies of energy conservation in proportion to the amount of conserved fuel.

- Extension of the Green Management concept beyond the higher educational centers and into the family management of the households. A proper consumption model is to be provided for the families.

- If the environmental accounting is conducted within the framework of the governmental and private institutions and companies' accounting system, then the implementation of Green Management is to be pursued diligently and seriously.

With the implementation of such policies it can be expected that during the fifth five year National Development plan, it is possible, according to present consumption rates, to reduce energy consumption by $20-30 \%$ and water usage by at least $10 \%$. This can also help to reduce the deforestation phenomenon in the Zagros and Caspian regional of Iran.

\section{References}

[1] Khadivi, S, 2005, "Green Management in Sporting Complexes (Enghelab Stadium)", M.Sc. thesis Science \& Research Campus, Islamic Azad University, Iran, Tehran 
[2] http://www.greengovernment.com/ir

[3] Abbaspour, M., Karbasi, A.R. \& Khadivi, S., 2006, "Minimization of Adverse Environmental Effects of a Sports Complex through Implementation of Green Management", the sustainable city IV, WIT, Tallinn, Estonia.

[4] Abbaspour, M., Karbasi, A.R. \& Khadivi, S., 2006, "Implementation of Green Management Concepts in Sport Complexes", International Journal of Environmental Science and Technology (IJEST), Vol. 3, No. 3

[5] http://www.irandoe.org

[6] The Air Pollution Assessment Office, 2003, "Public Transportation", the Higher Council of the Environment, National Committee of Sustainable Development, Bulletin No. 10, Department of Environment Publication, Iran.

[7] Riahi, M., 2004, "Establishment of Green Management System in the Executive Institutions as an Instrument for Implementation of National \& International Environmental and Economic Measures towards the Objectives of the $4^{\text {th }}$ Development Plan", The Fifth Biannual National Conference of the Iranian Society of Environmentalists, Iran, Tehran, ekocentrum@ekocentrum.nu 